\title{
A new ctenochasmatid pterosaur from the Lower Cretaceous, western Liaoning, China
}

\author{
SHUNXING JIANG ${ }^{1,2}$ and XIAOLIN WANG ${ }^{1}$ \\ ${ }^{1}$ Key Laboratory of Evolutionary Systematics of Vertebrates, Institute of Vertebrate Paleontology \\ and Paleoanthropology, Chinese Academy of Sciences, PO Box 643, Beijing, 100044, China \\ ${ }^{2}$ Graduate University of the Chinese Academy of Sciences, Beijing, 100049, China
}

Manuscript received on August 8, 2011; accepted for publication on September 28, 2011

\begin{abstract}
A nearly complete skull of a new ctenochasmatid pterosaur, Pterofiltus qiui gen. et sp. nov., from the Lower Cretaceous deposits of Liaoning, China, is described here. The specimen (IVPP V12339), was collected from the shale of the lower Yixian Formation (125 Ma) at the Zhangjiagou locality. It has the following combination of characters: about 112 teeth in total (including the upper and lower jaws); the dentition occupies more than 50\% of the skull length; the anterior teeth vary in size; the mandibular symphysis is longer than half of the whole mandible length; in ventral view, an apparent symphyseal trough in the median part of the symphysis.
\end{abstract}

Key words: Lower Cretaceous, Yixian Formation, Pterofiltus qiui, Ctenochasmatidae, Liaoning, China.

\section{INTRODUCTION}

The pterosaur record from China has yielded several important new taxa due to the collecting activities done particularly in western Liaoning (e.g., Wang et al. 2009, 2010). The most important deposits are known as the Jehol Biota that comprises numerous articulated fossils, from plants and insects to all kinds of vertebrates, making it one of the most amazing terrestrial Cretaceous ecosystems in the world (Chang et al. 2003, Zhou et al. 2003, Wang et al. 2008, Zhou and Wang 2010).

Since the first description of a pterosaur in 1997 (Ji and Ji 1997), many more pterosaur fossils have been discovered in the Jehol Biota. Among them, four ctenochasmatids play an important role in the pterosaur research: Beipiaopterus chenianus (Lü 2003), Cathayopterus grabaui (Wang and Zhou 2006), Gegepterus changae [nom. correct. Wang and Dong 2008 (pro

Correspondence to: Xiaolin Wang

E-mail: wangxiaolin@ivpp.ac.cn
Gegepterus changi Wang et al. 2007)] and Elanodactylus prolatus (Andres and Ji 2008). Most of them come from the Jianshangou Bed of the lower Yixian Formation, except Cathayopterus from the Dawangzhangzi Bed of the middle Yixian Formation.

Recently, another interesting specimen of a ctenochasmatid pterosaur was discovered from the Zhangjiagou locality near Beipiao City, Liaoning Province (Fig. 1). In the same locality, there are many other vertebrate fossils such as Dendrorhynchoides curvidentatus (Ji and Ji 1998, Wang and Lü 2001), Protarchaeopteryx robusta (Ji et al. 1998), Caudipteryx dongi (Zhou and Wang 2000), Caudipteryx zoui (Ji et al. 1998), and an immature iguanodontian. The specimen V 12339 consists of most part of skull and mandibles and was collected from the Jianshangou Bed of the lower Yixian Formation. It represents a new genus and species, Pterofiltrus qiui, which is described here. Additionally, we discuss the relationship between the new taxon and other ctenochasmatid pterosaurs. 


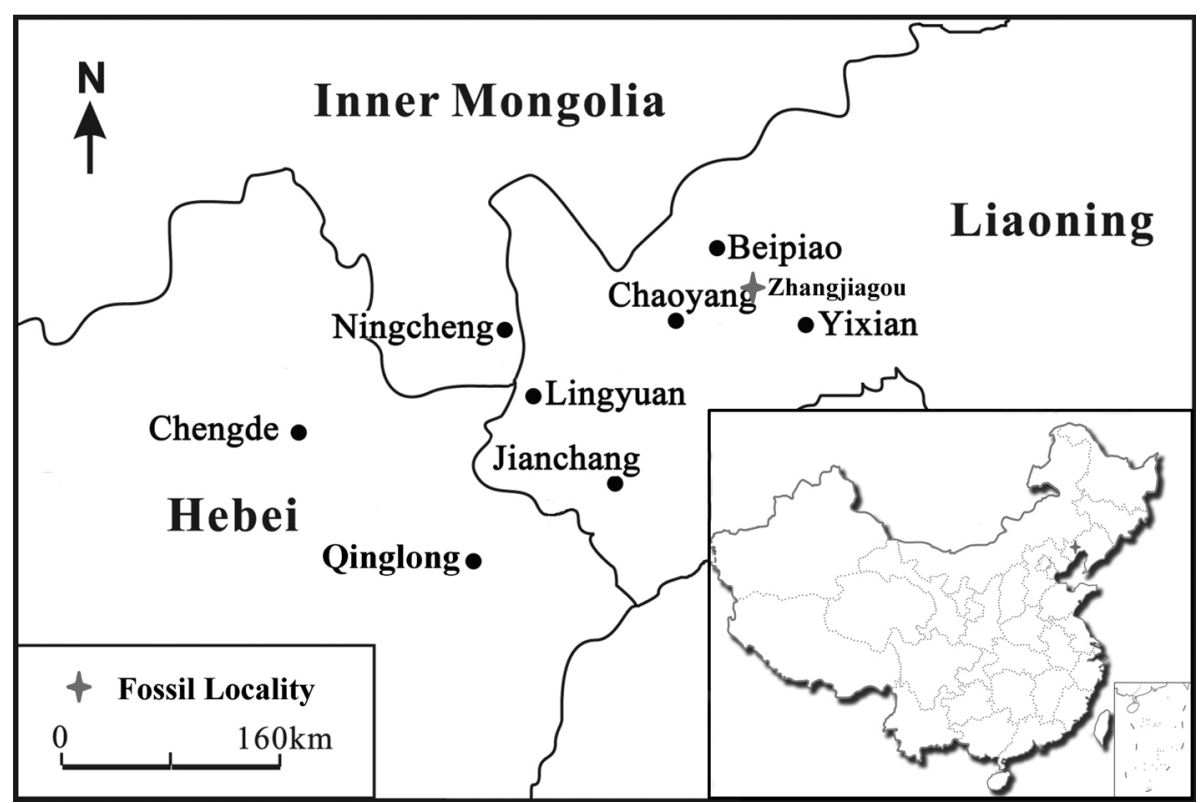

Fig. 1 - Sketch of the map of China with the indication of the fossil locality.

\section{SYSTEMATIC PALEONTOLOGY}

Pterosauria Kaup, 1834

Pterodactyloidea Plieninger, 1901

Archaeopterodactyloidea Kellner, 2003

Ctenochasmatidae Nopcsa, 1928

Pterofiltrus gen. nov.

Etymology - ptero-, from pteron (Greek), means wing; filtrus, from filtrum (Medieval Latin), means filter.

Type species - Pterofiltrus qiui gen. et sp. nov.

Diagnosis - As for the species.

\section{Pterofiltrus qiui sp. nov.}

Etymology - In honor of Prof. Qiu Zhanxiang, who has made great contributions to the Chinese paleontology.

Type specimen - IVPP V12339 (Fig. 2), most part of skull and mandible, and first two cervical vertebrae, housed in the Institute of Vertebrate Paleontology and Paleoanthropology (IVPP), Chinese Academy of Sciences, Beijing, China.

Locality and horizon - Zhangjiagou, Beipiao City, Liaoning Province, China. Jianshangou Bed, lower Yixian Formation, Lower Cretaceous, about $125 \mathrm{Ma}$ (Swisher et al. 2001).
Diagnosis - A Ctenochasmatid pterosaur with the following combination of characters that distinguish it from the other members of this clade (autapomorphies are marked with an asterisk): about 112 teeth in total (including the upper and lower jaws); the dentition occupies more than $50 \%$ of the skull length; the anterior teeth vary in size; the mandibular symphysis is longer than half of the whole mandible length*; in ventral view, an apparent symphyseal trough in the median part of the symphysis*.

\section{DESCRIPTION}

IVPP V12339 preserves nearly all elements of the skull, but they are not articulated (Fig. 2A, B). The estimated length of the skull is $208 \mathrm{~mm}$. The rostrum and the posterior part of the skull can be observed in both right and dorsal sides, respectively. The mandibles are preserved dorsoventrally flattened. Their posterior and anterior parts are respectively preserved in the dorsal and ventral sides, as the anterior part was turned over (Fig. 2C; showing the relationship of the main elements).

\section{Premaxilla AND MaXilla}

The premaxilla and maxilla are fused, and the suture between them is unclear (Fig. 2A, B, D). The premaxilla is very long, and it is estimated to extend to the posterior end of the nasoantorbital fenestra. The anterior tip 

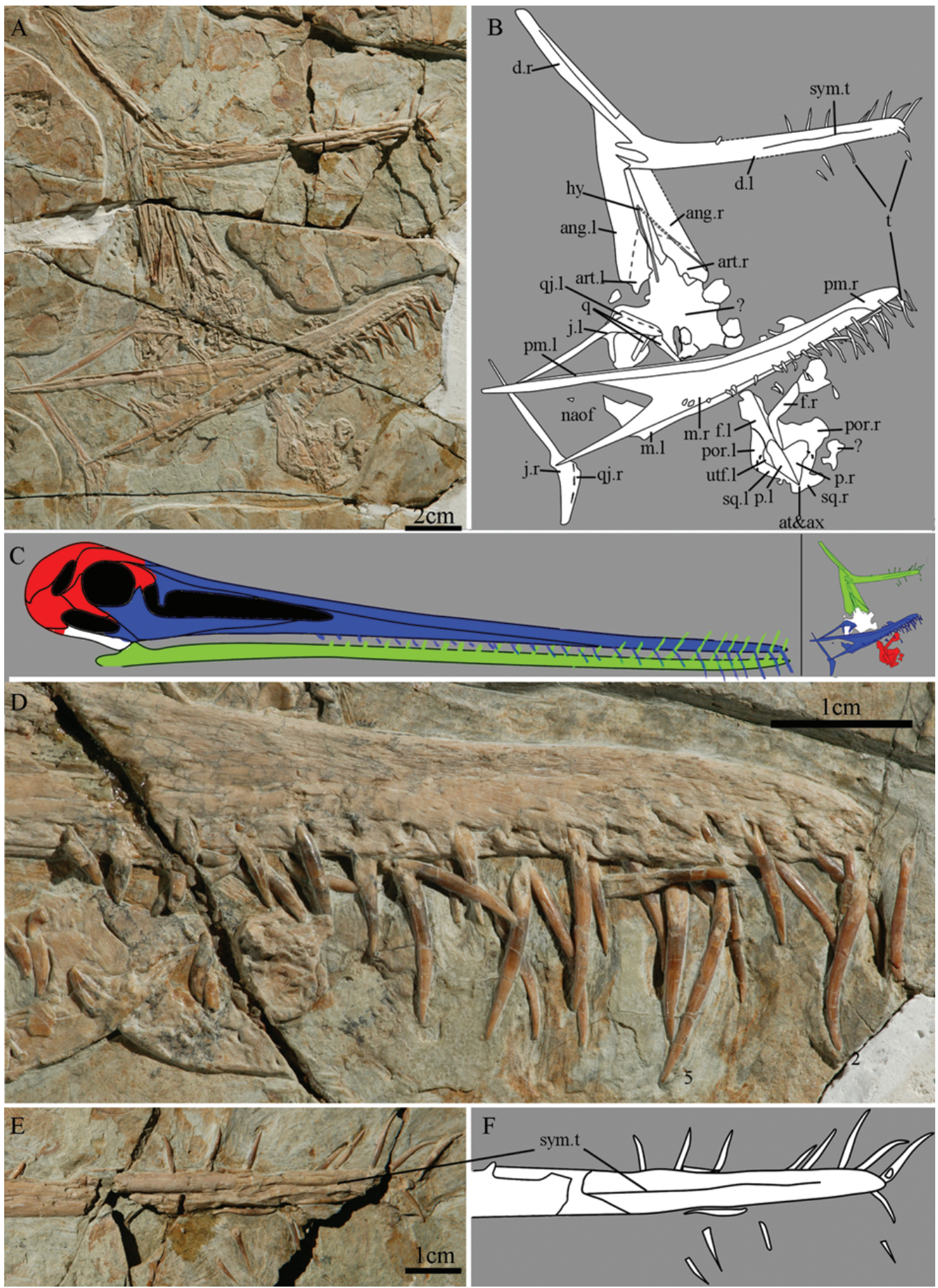

Fig. 2 - Pterofiltrus qiui gen. et sp. nov., IVPP V12339; photograph (A); line drawing (B) showing the general position of the elements; their relationship (C), blue, rostrum; green, mandible; red, posterior part of the skull; white, indeterminate; The anterior teeth in the upper jaw, the teeth are numbered based mainly on the presence of the alveoli. The $2^{\text {nd }}$ and $5^{\text {th }}$ teeth are the longest ones (D); photograph (E) and line drawing (F) of the anterior mandibles, the teeth are directed laterally, and the anterior teeth directed anterolaterally, which is an important feature of Ctenochasmatidae. ang, angular; art, articular; at, atlas; ax, axis; d, dentary; f, frontal; hy, hyoid; j, jugal; m, maxilla; naof, nasoantorbital fenestra; p, parietal; pm, premaxilla; por, postorbital; q, quadrate; qj, quadratojugal; sq, squamosal; sym.t, symphyseal trough; t, tooth; utf, upper temporal fenestra; 1 , left; r, right. 
of the premaxilla is not expanded like in some other ctenochasmatids, such as Plataleorhynchus and Gnathosaurus (Howse and Milner 1995). There is no crest on the maxilla or premaxilla. The maxilla is separated from the jugal, and exceeds the middle of the nasoantorbital fenestra, forming the ventral margin of the nasoantorbital fenestra.

There are 29 teeth on each side. The number of the teeth is mainly based on the alveoli on the specimen. The diameter of the anterior alveoli nearly equals the distance between two teeth. The density of them is 3.4 teeth $/ \mathrm{cm}(15$ teeth $/ 4.4 \mathrm{~cm})$. The teeth are inclined anteriorly, and the inclination angle becomes smaller from the anterior portion to the posterior portion. The anterior teeth have a $135^{\circ}$ angle to the ventral margin of the premaxilla, but the last few ones are nearly vertical. The anterior teeth vary in size. The $2^{\text {nd }}$ and $5^{\text {th }}$ teeth are the longest ones (Fig. 2D). The alveoli become shallower posteriorly. The teeth also become smaller and vary in shape. The anterior and posterior teeth are slender and triangular, respectively. The whole tooth row is about $116 \mathrm{~mm}$ long, $55.8 \%$ of the skull length, having a 2.5 teeth $/ \mathrm{cm}$ density on average.

\section{JUGAL, QUADRATOJUGAL AND QUADRATE}

Both jugals are preserved, but not in their original anatomic position. The right jugal is complete, and it is a triradiate bone. The anterior process is thin, smooth and very long, nearly $70 \%$ of the jugal length. The right dorsal process, which is in contact with the lacrimal, is preserved in a $60^{\circ}$ angle with the anterior process. Only some broken process remains on the left jugal. On the ventral side of the left jugal, the posterior process is fused with the quadratojugal, forming the anterior margin of the lower temporal fenestra, which is surrounded by the jugal, quadrate, quadratojugal, squamosal, and postorbital.

The quadratojugal is a V-shaped bone. One end fuses with the jugal without any perceptible suture, and the other one would fuses with the quadrate. However, a small glenoid cavity is found at the bottom of each quadratojugal where it would be in contact with the quadrate. In the specimen, some fragmentary bones are located between the upper and lower jaws. Two stick-like bones may both be quadrates. The putative right quad- rate has an expanded end, which would connect with the articular. The other end is laid by the premaxilla.

\section{Frontal, Parietal and Squamosal}

The posterior portions of both frontals are preserved. They are fused together and no suture can be observed. They taper posteriorly and wedge into the middle of the both parietals. There is no crest on the frontals. The right frontal is broken, and the upper temporal fenestra cannot be recognized. The left frontal is well preserved, surrounding the upper temporal fenestra with the parietal, squamosal, and postorbital. Because of the preservation, the posterior part of the eye socket is overlaid, and part of the upper temporal fenestra is visible.

Both parietals are fused together, and have a groove in the middle. The parietal is very smooth, and it is easy to distinguish it from the other bones. There is also no crest on the parietals. The squamosal is not well preserved. Only the outline can be recognized and the details are lost.

\section{MANDiBLE}

Both mandibles are narrow, with about $174 \mathrm{~mm}$ length. Both retroarticular processes are developed. The outlines of the angular and the surangular cannot be recognized. The dentary is the largest bone in the lower jaw. The tip of the dentary is not expanded. The anterior portions fuse together, forming a symphysis, which bears an apparent symphyseal trough in the ventral side (Fig. 2E, F). The symphyseal trough is nearly $5 \mathrm{~mm}$ depth and fills $26 \%$ of the mandible length. The surface of the symphysis is smooth. The symphysis occupies $58 \%$ of the mandible length.

The mandibles also have slender teeth. Because some teeth are lost and the alveoli are not exposed, the number of teeth is not certain. Considering the length of the tooth row, it should nearly subequal that of the upper jaw, so it may have 27 teeth per side. The mandible is preserved dorsoventrally flattened; the teeth are directed laterally, and only the anterior teeth are directed the anterolaterally (Fig. 2E, F).

\section{HYOID}

Although the anterior part of the hyoid is absent, both posterior rami are preserved. They are separated. 


\section{VERTEBRAE}

Only the first two cervical vertebrae, atlas and axis are preserved. They are fused together and their outline is not very clear.

\section{COMPARISON AND DISCUSSION}

The Ctenochasmatidae is part of the clade known as Archaeopterodactyloidea (Kellner 2003). Pterofiltrus qiui is assigned to the Ctenochasmatidae based on the extremely elongated rostrum, a large number of slender teeth, and the upper anterior teeth inclined ventroanteriorly.

There are five genera and species of ctenochasmatids reported in China (Dong 1982, Lü 2003, Wang and Zhou 2006, Wang et al. 2007, Andres and Ji 2008). Beipiaopterus and Elanodactylus are known only postcranial skeletons, which cannot be compared with the holotype of Pterofiltrus, whereas Huanhepterus, Cathayopterus and Gegepterus have partial or nearly complete skulls.

Cathayopterus and Pterofiltus share some important features. For example, the amounts of the teeth are similar, and the ratio of rostrum to skull length is more than 50\% (Wang and Zhou 2006). However, they have some significant differences. The teeth row of Pterofiltus exceeds the anterior margin of the nasoantorbital fenestra, while that of Cathayopterus does not reach the nasoantorbital fenestra. The teeth shapes are different in both pterosaurs. Cathayopterus lost the last few teeth, and only the alveoli left. The preserved teeth are slender, and only vary in size from the anterior to the posterior region. In Pterofiltus, the teeth can vary both in size and in shape, from the slender ones in the anterior portion to the triangular ones in the posterior portion.

Gegepterus has more complete and articulated skulls than that of Pterofiltus (Wang et al. 2007, Jiang and Wang 2011). It has a very low premaxillary crest, not found in Pterofiltus. Although some authors consider the cranial crests in the skull is considered as sexual dimorphism in some genera (for instance, Lü et al. 2011), this difference may not only related to sexual dimorphism, but also to an interspecific difference (Kellner 2010). The teeth of both pterosaurs are slender, but the posterior teeth of Pterofiltus are triangu- lar and reach the anterior margin of the nasoantorbital fenestra. The posterior teeth of Gegepterus are still slender, and the last tooth has a distance to the anterior margin of the nasoantorbital fenestra.

Huanhepterus has a skull (Dong 1982). Most elements of the postcranial skeleton are absent, but left some three dimensional impression in the sandstone. Although Huanhepterus is not complete, it is obviously larger than Pterofiltus. Huanhepterus has an apparent crest beginning at the anterior portion of the premaxilla, which is absent in Pterofiltus. Huanhepterus has about 25 teeth per jaw side, slightly fewer than Pterofiltus (27-29 teeth per jaw side). The density of teeth in Huanhepterus $(1.6$ teeth/cm) is less than that in Pterofiltus $(2.5$ teeth $/ \mathrm{cm})$. All teeth in Huanhepterus are similar, and they are not as slender as in other ctenochasmatids.

Compared with other ctenochasmatid pterosaurs, Pterofiltus is unique. Pterodaustro from the Lagarcito Formation, Lower Createous of Argentina, is very specialized, with nearly a thousand needle-like teeth on the upper jaws (Chiappe et al. 2000), and it is easy to distinguish it from Pterofiltus. Ctenochasma has three species, including $C$. roemeri, $C$. elegans and $C$. taqueti from the Upper Jurassic Solnhofen Limestone of Bavaria, Germany, Upper Jurassic Calcaires tachetés of eastern France and Lower Cretaceous "Purbeck" Formation of Deister Hill, Germany. Ctenochasma has more than 50 teeth per jaw side (Bennett 2007), and their density is much greater than in Pterofiltus. Plataleorhynchus from the Upper Jurassic or Lower Cretaceous Purbeck Limestone of Dorset, England, has only the part of the rostrum preserved, with an estimated skull length of at least $400 \mathrm{~mm}$, nearly twice of that in Pterofiltus $(208 \mathrm{~mm})$. Furthermore, Plataleorhynchus has an expanded spatulated rostrum (Howse and Milner 1995), which differs from Pterofiltrus. Gnathosaurus, including G. subulatus and G. macrurus from the Solnhofen Limestone and Purbeck Limestone, respectively, have expanded anterior tips and maxillary crests, which cannot be found in Pterofiltus. The symphyseal portion of the mandible is about $40 \%$ and $58 \%$ in Gnathosaurus and Pterofiltus, respectively. We observed a symphyseal trough on the dorsal side of the mandible in Pterofiltus, while the symphyseal trough is found on the ventral side in Gnathosaurus macrurus (Howse and Milner 1995). 
Boreopterus, from the Yixian Formation, resembles Pterofiltus regarding the very slender teeth of the rostrum tip (Lü and Ji 2005). The most marked difference is the direction of the teeth. In Boreopterus, the teeth are inclined anteriorly, while in Pterofiltus, they are inclined not only anteriorly but also ventrally, which is a significant character of the Ctenochasmatidae.

\section{CONCLUSIONS}

Based on a series of combination of characters, the new genus and species Pterofiltus qiui is established. The Jehol Biota comprises many pterosaurs and ctenochasmatids play a very important role. The amount of clade members is not big, but this clade has more taxa than many others. This new member provides further information on the global distribution of the ctenochasmatid, in Asia, Europe and America (Rodrigues and Kellner 2010).

\section{ACKNOWLEDGMENTS}

We thank Drs. Alexander W.A. Kellner (Museu Nacional/UFRJ, Rio de Janeiro, Brazil), Zhonghe Zhou (Institute of Vertebrate Paleontology and Paleoanthropology, Chinese Academy of Sciences, Beijing) and Desui Miao (Natural History Museum and Biodiversity Research Center, University of Kansas, Lawrence, USA) and two anonymous reviewers for their useful comments and English correction on the manuscript. We also thank Yutong Li for preparing the specimen and Jie Zhang for photographing. This study was supported by the National Science Fund for Distinguished Young Scholars (40825005), National Basic Research Program of China (973 Program) (2012CB821903) and National Natural Science Foundation of China (40121202), .

\section{RESUMO}

Um crânio quase completo de um novo pterossauro ctenochasmatídeo, Pterofiltus qiui gen. et sp. nov., de depósitos do Cretáceo Inferior de Liaoning, China é descrito. O exemplar (IVPP V12339) foi coletado de um argilito da parte inferior da Formação Yixian (125 Ma) na localidade Zhangjiagou. A nova espécie possui a seguinte combinação de caracteres: aproximadamente 112 dentes (incluindo ambas as arcadas); dentição ocupando mais de $50 \%$ do comprimento do crânio; dentes anteriores de tamanho variado; sínfise mandibular ocupando mais da metade do comprimento da mandíbula; abertura ventral na parte média da sínfise mandibular.

Palavras-chave: Cretáceo Inferior, Formação Yixian, Pterofiltus qiui, Ctenochasmatidae, Liaoning, China.

\section{REFERENCES}

ANDRES B AND Ji Q. 2008. A new pterosaur from the Liaoning Province of China, the phylogeny of the Pterodactyloidea, and convergence in their cervical vertebrae. Palaeontology 51: 453-469.

BENNETT SC. 2007. A review of the pterosaur Ctenochasma: taxonomy and ontogeny. Neues Jahrb Geol P-A 245(1): $23-31$.

Chang MM, Chen PJ, Wang YQ, Wang Y and Miao DS. 2003. The Jehol Biota, the Emergence of Feathered Dinosaurs, Beaked Birds and Flowering Plants, Shanghai: Shanghai Scientific \& Technical Publishers, 208 p.

Chiappe LM, Kellner AWA, Rivarola D, Davila S AND FOX M. 2000. Cranial morphology of Pterodaustro guinazui (Pterosauria: Pterodactyloidea) from the Lower Createous of Argentina. Nat Hist Mus Los Angeles County, Contrib Sci 483: 1-19.

Dong ZM. 1982. On a new Pterosauria (Huanhepterus quingyangensis gen. et sp. nov.) from Ordos, China. Vert PalAsit 20(2): 115-121 (in Chinese with English abstract).

Howse SCB AND MILNER AR. 1995. The pterodactyloids from the Purbeck Limestone Formation of Dorset. Bull Nat Hist Mus, London (Geol) 51(1): 73-88.

Ji Q, Currie PJ, Norell MA And Ji SA. 1998. Two feathered dinosaurs from the northeast China. Nature 393: 753-761.

JI SA AND JI Q. 1997. Discovery of a new pterosaur from the Lower Cretaceous of Chaoyang Basin, western Liaoning, China. Acta Geol Sin 71(1): 1-6 (in Chinese with English abstract).

JI SA AND JI Q. 1998. A new fossil pterosaur (Rhamphorhynchoidea) from Liaoning. Jiangsu Geol 22(4): 199 206 (in Chinese with English abstract).

JIANG SX AND WANG XL. 2011. Important features of Gegepterus changae (Pterosauria: Archaeopterodactyloidea, Ctenochasmatidae) from a new specimen. Vert PalAsit 49(2): 172-184.

Kellner AWA. 2003. Pterosaur phylogeny and comments on the evolutionary history of the group. In: BUfFETAUT E AND MAZIN JM (Eds), Evolution and Palaeobiology of Pterosaur, London: Geological Society, Special Publication, p. 105-137. 
Kellner AWA. 2010. Comments on the Pteranodontidae (Pterosauria, Pterodactyloidea) with the description of two new species. An Acad Bras Cienc 82(4): 1063-1084.

LÜ JC. 2003. A new pterosaur: Beipiaopterus chenianus, gen. et sp. nov. (Reptilia: Pterosauria) from western Liaoning Province of China. Mem Fukui Pref Dino Mus 2: 153-160.

LÜ JC AND JI Q. 2005. A new ornithocheirid from the early Cretaceous of Liaoning Province, China. Acta Geol Sin (Engl) 79(2): 157-163.

Rodrigues T AND Kellner AWA. 2010. Note on the pterosaur material described by Woodward from the Recôncavo Basin, Lower Cretaceous, Brazil. Rev Bras Paleontol 13(2): 159-164.

SWISHER III CC, WANG XL, ZHOU ZH, WANG YQ, JIN F, ZHANG JY, XU X, Zhang FC AND WANG Y. 2001. Further support for a Cretaceous age for the feathereddinosaur beds of Liaoning, China: New Ar-40/Ar-39 dating of the Yixian and Tuchengzi formations. Chin Sci Bull 47(2): 135-138.

WANG XL, CAmpos DA, ZHou ZH AND Kellner AWA. 2008. A primitive istiodactylid pterosaur (Pterodactyloidea) from the Jiufotang Formation (Early Cretaceous), northeast China. Zootaxa 1813: 1-18.

WANG XL AND Dong ZM. 2008. Order Pterosauria. In: Li JL, WU XC AND ZHANG FC (Eds), Chinese Fossil Reptiles and Their Kin, $2^{\text {nd }}$ ed., Beijing: Science Press, p. 215-234.

Wang Xl, Kellner AWA, Jiang SX, Cheng X, Meng X AND Rodrigues T. 2010. New long-tailed pterosaurs (Wukongopteridae) from western Liaoning of China. An Acad Bras Cienc 82(4): 1045-1062.
Wang XL, Kellner AWA, Jiang S And Meng X. 2009. An unusual long-tailed pterosaur with elongated neck from western Liaoning of China. An Acad Bras Cienc 81(4): 793-812.

WANG XL, Kellner AWA, Zhou ZH AND CAMPos DA. 2007. A new pterosaur (Ctenochasmatidae, Archaeopterodactyloidea) from the Lower Cretaceous Yixian Formation of China. Cretaceous Res 28(2): 245-260.

WANG XL AND LÜ JC. 2001. Discovery of a pterodactylid pterosaur from the Yixian Formation of western Liaoning, China. Chin Sci Bull 46(13): 1112-1117.

WANG XL AND ZHOU ZH. 2006. Pterosaur radiation of Jehol Biota and their paleoenvironment. In: RONG JY (Eds), Originations, Radiations and Biodiversity ChangesEvidences from the Chinese Fossil Record, Beijing: Science Press, p. 665-689, 937-938 (in Chinese).

Zhou ZH, BARrett PM AND Hillton J. 2003. An exceptionally preserved Lower Cretaceous ecosystem. Nature 421: 807-814.

Zhou ZH AND WANG XL. 2000. A new species of Caudipteryx from the Yixian Formation of Liaoning, Northeast China. Vert PalAsit 38(2): 111-127.

ZHOU ZH AND WANG Y. 2010. Vertebrate diversity of the Jehol Biota as compared with other lagerstätten. Sci China Earth Sci 53: 1894-1907. doi: 10.1007/s11430010-4094-9 